\title{
PRELIMINARY EVALUATION OF VARIOUS INTRODUCED VARIETIES OF YAMI
}

Yams (Dioscorea sp.) are an important part of the Puerto Rican diet. Local production must be supplemented by importation to satisfy demand.

In our continuous search for better yam varieties, new introductions are obtained from different countries. Before these are released to the public as new, they are planted in various regions on the Island to observe their behavior.

Seven yam varieties were planted on May 26, 1971 at Rio Piedras in a

TABLE 1.-Total, mean and estimated yields per acre, visual ratings as to resistance to candelilla and tuber descriptions of seven yam varieties planted at Rio Piedras, May 26,1971

\begin{tabular}{|c|c|c|c|c|c|}
\hline Variety & $\begin{array}{l}\text { Total } \\
\text { yield }\end{array}$ & $\begin{array}{l}\text { Meaan } \\
\text { yield } \\
\text { plot }\end{array}$ & $\begin{array}{l}\text { Estimated } \\
\text { yield/A }\end{array}$ & Rating & $\begin{array}{l}\text { Description } \\
\text { of tuber }\end{array}$ \\
\hline & Pounds & Pounds & Crot. & & \\
\hline Guinea amarillo & 75.22 & 23.55 & $569.91 \mathrm{a}^{1}$ & $1^{2}$ & Long, root-free \\
\hline $\begin{array}{l}\text { Farm Lisbon (P.I. } \\
7627 \text { ) }\end{array}$ & 45.55 & 17.84 & $432.73 a, b$ & 2 & $\begin{array}{l}\text { Like baseball } \\
\text { glove }\end{array}$ \\
\hline Oriental (P.I. 7625) & 42.72 & 16.26 & 393.49 a,b,c & 2 & Ovoid, root-free \\
\hline Barbados (P.I. 7621) & 41.54 & 12.23 & 298.37 b,c & 2 & Do. \\
\hline Seal Top (P.I. 7620) & 35.48 & 11.69 & 282.89 b,c & 2 & Do. \\
\hline Florido & 32.18 & 11.10 & $268.62 \mathrm{~b}, \mathrm{c}$ & 3 & Do. \\
\hline $\begin{array}{l}\text { Smooth Statia (P.I. } \\
7626)\end{array}$ & 27.17 & 7.29 & $176.42 \mathrm{~b}, \mathrm{c}$ & 3 & Long, root-free \\
\hline
\end{tabular}

1 Values not followed by same letter statistically different at 5-percent level.

2 Candelilla resistance ratings: 1) free, 2) infected, 3) heavily infected.

balanced incomplete block design. Six of these were Dioscorea alata L. ${ }^{2}$ (Seal Top (P.I. 7620), Barbados (P.I. 7621), Oriental (P.I. 7625), Smooth Statia (P.I. 7626), Farm Lisbon (P.I. 7627) and Florido) and one was D. cayenensis Lam.", known in Puerto Rico as "guinea amarillo." They were planted in concrete beds 20 feet long and 3 feet wide. The beds were filled with a mixture of alluvial soil and cured (sugarcane) filter press cake in a proportion of one to one. Each bed was divided into three plots. Each plot had four plants in a single row 11/2 feet between plants. All plants were staked and a 10-6-20 fertilizer at the rate of 1,000 lb. per acre was applied to each plant. The plants were harvested January 5, 1972 when the vines dried up, about seven and a half months after planting.

1 Manuscript submitted to Editorial Board June 20, 1974.

a Coursey, D. C., Yams, Longmans, Green and Co. Ltd., 1967. 
Table 1 presents yields, ratings to resistance to "candelilla" disease (Colletotrichum gloeosporioides), and furnishes a brief description of the shape of the tuber of the seven varieties.

The statistical analysis of the yield data indicates significant differences between some of the varieties. The highest yielder was variety Guinea amarillo with an estimated yield of $569.91 \mathrm{cwt} / \mathrm{A}$, followed by Farm Lisbon, Oriental and Barbados with 432.73, 393.49 and 298.37 cwt/A, respectively. The yield of Guinea amarillo was better at the 1-percent level than that of Smooth Statia and better at the 5-percent level than Florido, Seal Top and Barbados. Although Farm Lisbon is a good yielder, the tuber has the form of a baseball glove and thus not recommended. Oriental, Barbados, Seal Top and Smooth Statia varieties produce ovoid tubers free of roots. Those of Guinea amarillo and Florido are long and also free of roots.

Guinea amarillo was the only variety found free of the disease "candelilla". Varieties Florido and Smooth Statia were heavily infected; Farm Lisbon, Seal Top, Oriental and Barbados showed less infection. The heavier the infection by "candelilla," the lower the yields of the varieties studied.

Oscar Danilo Ramirez Plant Breeding Department Agricultural Experiment Station Rio Piedras, Puerto Rico 